\title{
EMBRYOTOXICITY AND TERATOGENICITY OF FIPRONIL IN RATS
} (Rattus norvegicus)

\author{
Amal A. Eisa ${ }^{1 *}$, G.E. Abo-Elghar ${ }^{1}$, I.M. Ammar ${ }^{1}$, Hala G. Metwally ${ }^{2}$ and Samah S. Arafa ${ }^{1}$ \\ 1. Pest. Dept., Fac. Agric., Menoufia Univ., Egypt \\ 2. Clin. Pathol. Dept., Fac. Med., Cairo Univ., Egypt
}

Received: 09/07/2017 ; Accepted: 30/07/2017

\begin{abstract}
Teratogenic and embryotoxic effects of fipronil insecticide were studied following orally intubation of pregnant female rats. The animals were treated with different doses $1 / 10 \operatorname{LD}_{50}(2.1$ $\mathrm{mg} / \mathrm{kg} \mathrm{b} . \mathrm{wt})$ and $1 / 30 \mathrm{LD}_{50}(0.7 \mathrm{mg} / \mathrm{kg} \mathrm{b} . \mathrm{wt})$ at the $6^{\text {th }}$ to $15^{\text {th }}$ days of pregnancy (time of organogenesis). At the $20^{\text {th }}$ days of pregnancy, pregnant females were subjected to a caesarean section. The effect of the fipronil on fetal development was evaluated. Maternal weight gain decreased at 1/10 and 1/30 $\mathrm{LD}_{50}$ of fipronil. The body weight and length of viable fetuses significantly decreased with both tested doses. Visceral examination revealed cleft palate, heart and lungs hypoplasia, liver and kidneys atrophy increased with fipronil treatments at different doses. Skeletal examination showed incomplete ossification of the skull bones, short ribs, coccygeal absences, sternbrae abscence and digits of fore and hind limbs.
\end{abstract}

Key words: Fipronil, Rattus norvegicus, teratogenicity, visceral anomalies, skeletal abnormalities.

\section{INTRODUCTION}

Disorders of reproduction and hazards to reproductive health have become a prominent public health issue. Numerous agents including pesticides, plasticizers, metals and several industrial chemicals have been shown to cause reproductive toxicity in male and female laboratory animals and humans (Dalsenter et al., 1997; Faqi et al., 1998; Gray et al., 1999). Extensive usage of these pesticides in agriculture and residential setting cause chronic neurologic syndromes, teratogenicity, male reproductive failure, fetal growth retardation, embryo fetotoxicity and genotoxicity. Fipronil is a second-generation phenylpyrazole insecticide widely used in veterinary medicine as well as a food-use pesticide. It is effective at low doses against numerous terrestrial insects, such as insect pests of crops and locusts. Occupational exposure to fipronil may occur through inhalation of dust and dermal contact with this compound at workplaces where fipronil is produced or used Hazardous Substances Database (HSDB). In recent years there is great concern that pesticides may modify the normal functioning of human and wildlife endocrine system. Fipronil is an insecticide listed as a possible endocrine disruptor chemical (Ohi et al., 2004).

The purpose of the present study was to elucidate the effect of fipronil at sublethal doses $\left(1 / 10\right.$ and $\left.1 / 30 \quad L_{50}\right)$ on rats' embryos of pregnant female rats acutely exposed by oral administration of a formulated product.

\section{MATERIALS AND METHODS}

Rats' age average between 3-5 months, and their weight were between 120-200 g. They were procured from the holding company of biological vaccines (Vacsera), Cairo, Egypt. The animals were kept under specific conditions on a constant $12 \mathrm{hr}$., light/dark cycle and controlled temperature $\left(20-26^{\circ} \mathrm{C}\right)$. Standard pellet food and tap water were available ad libitum. Vaginal

\footnotetext{
*Corresponding author: Tel.: +20107116077

E-mail address: samahsaiad.88@gmail.com
} 
smears from each rat were monitored daily and only regular-cycling females were used for the experiments (Chahoud and Kwasigroch, 1977; US EPA, 1996). Male rats were mated with regular-cycling females (1:2) and only those that were able to impregnate both females were used in the experiments. The Fipronil commercial formulation, containing $5 \%$ fipronil $[( \pm)-5-$ amino -3- cyano -1- [2,6-dichloro----trifluoro-ptolyl) -4- trifluoromethyl sulfinyl pyrazolecarbonitrile] was used. In this investigation the treated animals were orally treated with $1 / 10$ and $1 / 30 \mathrm{mg} / \mathrm{kg}$.

Adult female rats were mated overnight with potentially fertile males. Vaginal smears were collected and examined for the presence of sperm. The day of sperm detection in vaginal smears was considered as day 0 of pregnancy Organisation for Economic Co-operation and Development (OECD) guidelines for Testing of chemicals, Section 4 (2001).

The mating procedure was repeated until a sufficient number of pregnant rats were obtained (3 per group). Pregnant females were weighed and randomly disturbed into 3 groups and treated as follows: Group 1: served as control and received an equal volume of distilled water similar to those treated with both doses. Group 2: received a $1 / 10 \mathrm{LD}_{50}(2.1 \mathrm{mg} / \mathrm{kg}$ b.wt $)$ of fipronil. Group 3: received a $1 / 30 \mathrm{LD}_{50}(0.7 \mathrm{mg} /$ $\mathrm{kg}$ b.wt) of fipronil. Dams were treated orally with doses of fipronil $1 / 10$ and $1 / 30 \mathrm{mg} / \mathrm{kg}$ at the $6^{\text {th }}$ to $15^{\text {th }}$ days of pregnancy. Body weight was recorded daily during pregnancy. Both ovaries and uterine horns of each dam were exteriorized of the surrounding fat and kept their sides. Live and dead were recovered and data were recorded. The uteruses from pregnant rats were weighed, and then detected the weight of fetuses, placenta, and the number of live and dead embryos, resorption embryos, malformed embryo and the number of corpora lutea.

Live foetuses were weighed, measured the crown to rump length and examined for any morphological abnormalities including a cleft palate. One half of the fetuses were randomly selected and preserved in Bouin's solution for the assessment of internal soft tissue anomalies using Wilson's free hand razor blade technique
(Wilson, 1965). For evaluation the skeletal defects, the remaining fetuses were eviscerated which were previously kept in 95\% ethyl alcohol for 7 days. They were stained with alizarin red (s) as described by Staples and Schnell (1964). Muscles of these foetuses were first digested by $2 \%$ potassium hydroxide for 6 24 hours according to the size of foetuses. Then were immersed in Mallsch's solution with alizarin red for 24 hours. The stained foetuses were kept in Mallsch's solution alone for 2 days, then rinsed in cold water and cleared by successive passage in graded concentrations $(50,70,90$ and $100 \%)$ of glycerol solution.

\section{Statistical Analysis}

The data were analysed using the statistical package SPSS for windows. Numerical values were reported as mean \pm SE of the sample size. $\mathrm{P}$ value $\leq 0.05$ was considered as statistically significant.

\section{RESULTS}

This study was carried out to explore the expected teratogenic activity of fipronil on pregnant rats. The effect of insecticide on several criteria in pregnant female rats such as: maternal body weight, placentas weight, uteruses weight, implantation sites and fetuses' weight and length.

Results presented in Table 1 clearly show the effect of fipronil oral administration to pregnant rats at $1 / 10 \mathrm{LD}_{50}(2.1 \mathrm{mg} / \mathrm{kg}$ b.wt $)$ and $1 / 30 \mathrm{LD}_{50}$ $(0.7 \mathrm{mg} / \mathrm{kg}$ b.wt) on body weight. Data showed a dose dependent effect. Body weight did not show any significant change when compared with control.

Results in Table 2 revealed that placenta weight in the treatment of $1 / 10$ of the $\mathrm{LD}_{50}$ of fipronil was significantly decreased comparing with control and the same result was obtained in uterus weight, but did not show any significance. On the other hand placenta in the treatment of $1 / 30 \mathrm{LD}_{50}(0.7 \mathrm{mg} / \mathrm{kg}$ b.wt $)$ was not significantly decreased compared with control. Whereas, uterus weight did not show any significant effect. 
Table 1. Effects of orally administered of fipronil into female rats by $1 / 10$ and $1 / 30 \mathrm{LD}_{50}$ on group maternal weight and experimental groups treated from the $6^{\text {th }}$ to $15^{\text {th }}$ days of gestation

\begin{tabular}{|c|c|c|c|c|c|}
\hline \multirow[t]{2}{*}{ Treatment } & \multicolumn{5}{|c|}{ Body weight (g) } \\
\hline & Day 0 & Day 6 & Day 15 & Day 20 & Gain (\%) \\
\hline $\begin{array}{l}\text { Fipronil 1/10 LD } \\
(2.1 \mathrm{mg} / \mathrm{kg} \mathrm{b.wt})\end{array}$ & $177.23 \pm 10.84$ & $185.68 \pm 10.05$ & $205.88 \pm 13.64$ & $213.38 \pm 13.47$ & $20.40 \%$ \\
\hline $\begin{array}{l}\text { Fipronil } 1 / 30 \mathrm{LD}_{50} \\
(0.7 \mathrm{mg} / \mathrm{kg} \mathrm{b.wt})\end{array}$ & $176.82 \pm 2.66$ & $183.27 \pm 2.94$ & $197.87 \pm 1.02$ & $216.88 \pm 0.45$ & $22.66 \%$ \\
\hline Control & $175.84 \pm 1.11$ & $189.01 \pm 0.53$ & $207.03 \pm 2.24$ & $223.18 \pm 0.90$ & $26.92 \%$ \\
\hline
\end{tabular}

Table 2. Effects of oral administration of fipronil with $1 / 10$ and $1 / 30 \mathrm{LD}_{50}$ on placenta and uterus weight in treated pregnant rats

\begin{tabular}{lcccc}
\hline Treatment & \multicolumn{2}{c}{ Placenta weight mean (g) } & \multicolumn{2}{c}{ Uterus weight mean (g) } \\
\cline { 2 - 5 } & Absolute & Relative (\%) & Absolute & Relative (\%) \\
\hline $\begin{array}{l}\text { Fipronil 1/10 LD } \\
\mathbf{5 0}\end{array}$ & $2.73 \pm 0.24^{*}$ & 1.26 & $3.28 \pm 0.44$ & 0.13 \\
$\begin{array}{l}\mathbf{2 . 1} \mathbf{~ m g / k g ~ b . w t )} \\
\text { Fipronil } \mathbf{~ 1 / 3 0 ~ L D ~}\end{array}$ & & & \\
$(\mathbf{0 . 7} \mathbf{~ m g / k g ~ b . w t )}$ & $4.29 \pm 0.44$ & 2.01 & $2.4 \pm 0.83$ & 0.46 \\
Control & $4.81 \pm 0.52$ & 2.16 & $3.62 \pm 0.54$ & 1.62 \\
\hline
\end{tabular}

$\mathrm{LSD}=0.05$

Results presented in Table 3 clarify the toxic effects of fipronil on number of fetuses, implantation sites, resorbed fetuses (Figs. 1 and 2), fetal weight and length. Fetal weight and length were decreased significantly when compared with control (Fig. 3). Number of fetuses, implantation sites and resorbed fetuses did not show significant change.

Malformations of obtained fetuses on head, thorax and abdomen of their mother treated rats at $1 / 10 \mathrm{LD}_{50}(2.1 \mathrm{mg} / \mathrm{kg} \mathrm{b.wt})$ and $1 / 30 \mathrm{LD}_{50}$ $(0.7 \mathrm{mg} / \mathrm{kg} \mathrm{b.wt})$ of fipronil are presented in Table 4 . The cleft palate at $1 / 30$ of the $\mathrm{LD}_{50}$ was significantly increased when compared with control (Fig. 4). Whereas, the cleft palate at 1/10 of the $\mathrm{LD}_{50}$, hypoplasia of heart and lungs and atrophy in liver and kidneys in both tested doses did not show any significant change (Figs. 5 and 6).

In our study of the deleterious effects of fipronil on skull cranial bone, absence of coccygeal vertebrae and absence of sternbrae. There was a significant increased absence of coccygeal vertebrae and sternbrae with $1 / 10$ $\operatorname{LD}_{50}(2.1 \mathrm{mg} / \mathrm{kg}$ b.wt $)$ and $1 / 30 \mathrm{LD}_{50}(0.7 \mathrm{mg} / \mathrm{kg}$ b.wt) compared with control (Figs. 8 and 9). Skull cranial bone and shortage ribs with $1 / 10$ of the $\mathrm{LD}_{50}$ were increased significantly when compared with control (Figs. 7 and 10). Whereas, skull cranial bone and shortage ribs with $1 / 30$ of the $\mathrm{LD}_{50}$ did not show any significant change. 
Table 3. Effects of oral administration of fipronil with $1 / 10$ and $1 / 30 \mathrm{LD}_{50}$ to pregnant rats from the $6^{\text {th }}$ to $15^{\text {th }}$ days of gestation on obtained fetuses

\begin{tabular}{|c|c|c|c|c|c|}
\hline Treatment & $\begin{array}{l}\text { No. of } \\
\text { fetuses }\end{array}$ & $\begin{array}{c}\text { Mean } \\
\text { implantation sites }\end{array}$ & $\begin{array}{c}\text { Resorbed fetuses } \\
\text { mean }(\%)\end{array}$ & $\begin{array}{c}\text { Fetal weight } \\
\text { (g) }\end{array}$ & $\begin{array}{l}\text { Fetal } \\
\text { length }\end{array}$ \\
\hline $\begin{array}{l}\text { Fipronil 1/10 LD } \\
(2.1 \mathrm{mg} / \mathrm{kg} \mathrm{b.wt})\end{array}$ & $24 \pm 0.58$ & $9.33 \pm 0.67$ & $\begin{array}{c}1.67 \pm 0.67 \\
6.95\end{array}$ & $21.06 \pm 1.42 *$ & $3.77 \pm 0.03 *$ \\
\hline $\begin{array}{l}\text { Fipronil } 1 / 30 \mathrm{LD}_{50} \\
(0.7 \mathrm{mg} / \mathrm{kg} \mathrm{b.wt})\end{array}$ & $24 \pm 1.00$ & $8.67 \pm 0.67$ & $\begin{array}{l}0.67 \pm 0.33 \\
2.79\end{array}$ & $22.08 \pm 1.03 *$ & $4.27 \pm 0.03 *$ \\
\hline Control & $26 \pm 0.67$ & $9.33 \pm 0.67$ & $\begin{array}{c}0.67 \pm 0.67 \\
2.57\end{array}$ & $34.87 \pm 2.85$ & 5.330 .17 \\
\hline
\end{tabular}

$\mathrm{LSD}=0.05$

Table 4. Effects of oral administration of fipronil with $1 / 10$ and $1 / 30 \mathrm{LD}_{50}$ to pregnant rats from the $6^{\text {th }}$ to $15^{\text {th }}$ days of gestation on visceral malformations of fetuses

\begin{tabular}{|c|c|c|c|c|c|c|}
\hline \multirow[t]{3}{*}{ Treatment } & \multirow{3}{*}{$\begin{array}{l}\text { No. of } \\
\text { fetuses }\end{array}$} & \multicolumn{5}{|c|}{ Malformation of } \\
\hline & & \multirow{2}{*}{$\begin{array}{c}\text { Head } \\
\text { Cleft } \\
\text { palate }\end{array}$} & \multicolumn{2}{|c|}{ Thorax } & \multicolumn{2}{|c|}{ Abdomen } \\
\hline & & & $\begin{array}{l}\text { Hypoplasia } \\
\text { of heart }\end{array}$ & $\begin{array}{l}\text { Hypoplasia } \\
\text { of lungs }\end{array}$ & $\begin{array}{c}\text { Atrophy } \\
\text { of liver }\end{array}$ & $\begin{array}{c}\text { Atrophy } \\
\text { of kidneys }\end{array}$ \\
\hline \multicolumn{7}{|l|}{$\overline{\text { Fipronil 1/10 LD }}$ 50 } \\
\hline$(2.1 \mathrm{mg} / \mathrm{kg} \mathrm{b.wt})$ & 12 & $2 \pm 0.58$ & $2 \pm 0.00$ & $1.67 \pm 0.88$ & $3 \pm 1.00$ & $4 \pm 0.00$ \\
\hline \multicolumn{7}{|l|}{ Fipronil $1 / 30 \mathbf{L D}_{50}$} \\
\hline$(0.7 \mathrm{mg} / \mathrm{kg} \mathrm{b.wt})$ & 13 & $2.67 \pm 0.88^{*}$ & $2 \pm 1.53$ & $1.67 \pm 0.33$ & $1.67 \pm 1.67$ & $2 \pm 0.00$ \\
\hline Control & 13 & -- & -- & -- & -- & -- \\
\hline
\end{tabular}

$\overline{\mathrm{LSD}}=0.05$

Table 5. Effects of oral administration of fipronil with $1 / 10$ and $1 / 30 ~ L D_{50}$ to pregnant rats from the $6^{\text {th }}$ to $15^{\text {th }}$ days of gestation on skeletal malformations of fetuses

\begin{tabular}{|c|c|c|c|c|c|c|}
\hline \multirow[t]{2}{*}{ Treatment } & \multirow{2}{*}{$\begin{array}{l}\text { No. of } \\
\text { fetuses }\end{array}$} & \multicolumn{5}{|c|}{ Malformation of } \\
\hline & & $\begin{array}{r}\text { Skull cranial } \\
\text { bone absent }\end{array}$ & $\begin{array}{c}\text { Coccygeal } \\
\text { vertebrae absent }\end{array}$ & $\begin{array}{c}\text { Sternbrae } \\
\text { absence }\end{array}$ & $\begin{array}{c}\text { Ribs } \\
\text { shortage }\end{array}$ & $\begin{array}{c}\text { Limbs } \\
\text { absence }\end{array}$ \\
\hline $\begin{array}{l}\text { Fipronil 1/10 LD } \\
(2.1 \mathrm{mg} / \mathrm{kg} \mathrm{b.wt})\end{array}$ & 12 & $3 \pm 1.15^{*}$ & $4 \pm 0.58^{*}$ & $4 \pm 0.58^{*}$ & $4 \pm 1.15^{*}$ & $4 \pm 1.15^{*}$ \\
\hline $\begin{array}{l}\text { Fipronil } 1 / 30 \mathrm{LD}_{50} \\
(0.7 \mathrm{mg} / \mathrm{kg} \mathrm{b.wt})\end{array}$ & 11 & $1.33 \pm 0.33$ & $3.33 \pm 0.33^{*}$ & $\begin{array}{l}2.33 \pm \\
0.67 *\end{array}$ & $3 \pm 1.15$ & $3 \pm 0.58 *$ \\
\hline Control & 13 & -- & -- & -- & -- & -- \\
\hline
\end{tabular}

$\mathrm{LSD}=0.05$ 


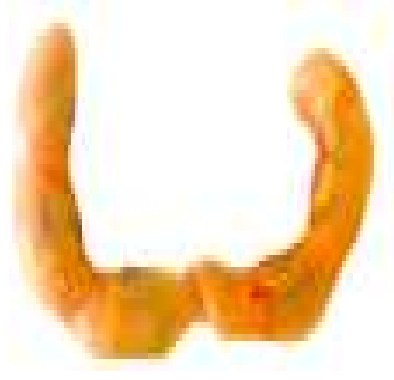

Fig. 1. Uterus obtained from control

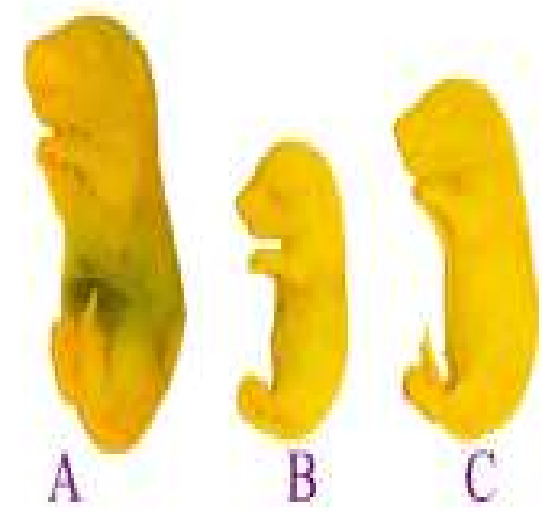

A : Cont. B: Fipronil (2.1 mg/kg b.wt) C: Fipronil (0.7 mg/kg b.wt)

Fig. 3. Lateral view of rat fetuses obtained from dams treated orally with fipronil during the organogenesis period showing growth retardation

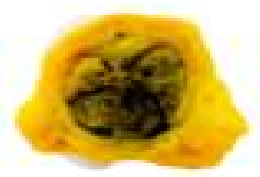

A

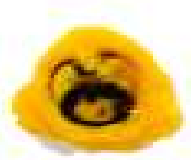

B

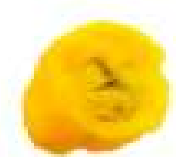

C
A : Cont. B: Fipronil (2.1 mg/kg b.wt) C: Fipronil (0.7 mg/kg b.wt)

Fig. 5. Transverse section in the chest of rat fetuses obtained from dams treated orally with fipronil during the organogenesis period showing heart and lung hypoplasia and liver atrophy

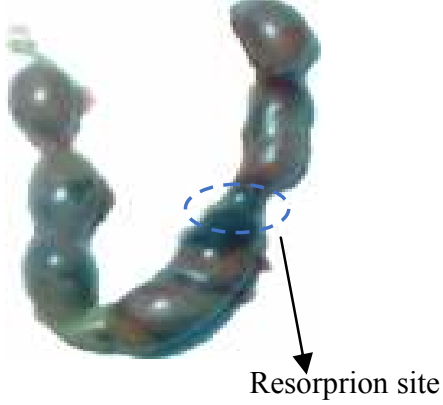

Fig. 2. Resorption sites on uterus obtained from treated dam with fipronil

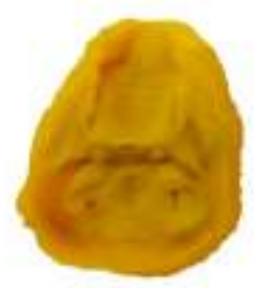

A

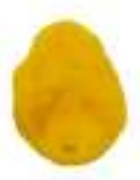

B

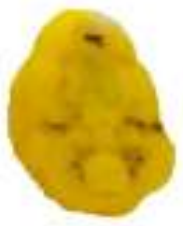

C
A : Cont. B: Fipronil (2.1 mg/kg b.wt) C: Fipronil (0.7 mg/kg b.wt)

Fig. 4. Cleft palate of a fetus obtained from dams after orally administration of fipronil

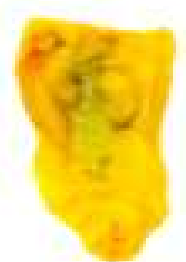

A

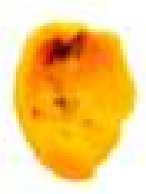

B

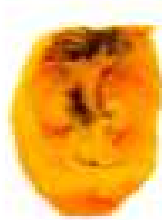

C
A : Cont. B: Fipronil (2.1 mg/kg b.wt) C: Fipronil (0.7 mg/kg b.wt)

Fig. 6. Atrophy of kidneys in rat fetus obtained from dams treated orally with fipronil during the organogenesis period 


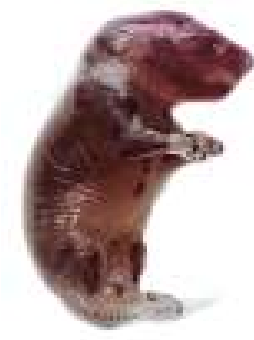

A

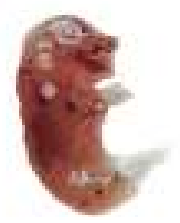

B

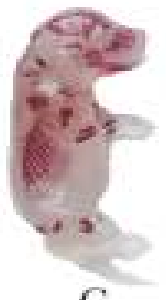

C
Eisa, et al.

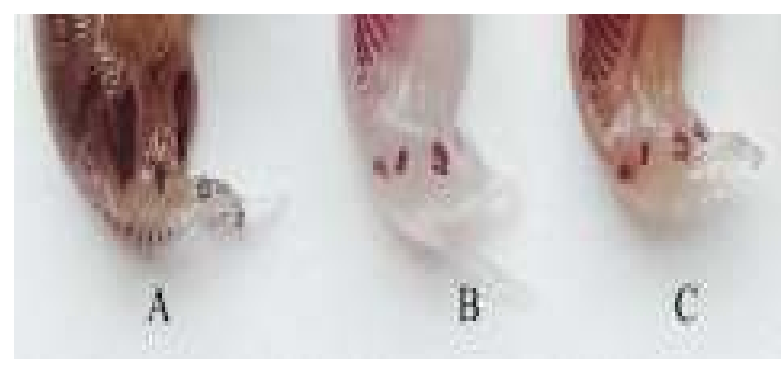

A : Cont. B: Fipronil (2.1 mg/kg b.wt) C: Fipronil (0.7 mg/kg b.wt)

Fig. 8. Absence of coccygeal vertebrae of a fetus obtained from dams treated orally with fipronil

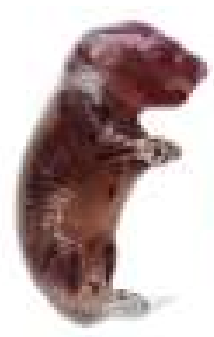

A

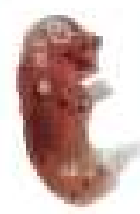

B

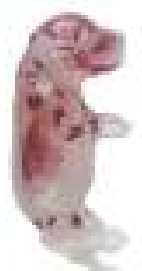

C
A : Cont. B: Fipronil (2.1 mg/kg b.wt) C: Fipronil (0.7 mg/kg b.wt)

Fig. 9. Sternbrae absence of a fetus obtained from dams treated orally with fipronil

\section{DISCUSSION}

In this research we tried to clarify the effects of fipronil to clear the deleterious effects induced by the insecticide when the female rats were treated orally through 10 days during organogenesis period with a high dose $(1 / 10$ $\operatorname{LD}_{50}(2.1 \mathrm{mg} / \mathrm{kg}$ body weight $)$ and a lower dose as $1 / 30 \mathrm{LD}_{50}(0.7 \mathrm{mg} / \mathrm{kg} \mathrm{b} . \mathrm{wt})$.

Fipronil induced different effects on maternal body weight, placenta and uterus weight, No. of fetuses, implantation sites, resorbed fetuses, No. of litters and fetal weight and length. Moreover, it causes malformations in head, thorax and abdomen regions, ribs shortage and limbs. Pesticides have a variety of effects on reproduction in exposed animals and humans.
A : Cont. B: Fipronil (2.1 mg/kg b.wt) C: Fipronil (0.7 mg/kg b.wt)

Fig. 10. Absence of fore and hind limbs digits and ribs shortage in fetuses obtained from dams treated orally with fipronil

Exposure of pregnant mothers to toxic substances has deleterious effects on both mothers and their fetuses, many authors cleared this fact. Reduction in body weight are sensitive indices of toxicity after exposure to toxic substances (Teo et al., 2002). In our research the reduction of body weight gain was obvious in the treatment of fipronil comparing to the control.

Others also recorded these effects after treatment of different pesticides (Nittin et al., 2007; Abou-Amer et al., 2010; Yu et al., 2015). Changes in the body weight after insecticides dosing was used as a viable index of insecticide related (Lu, 1996; Mansour and Mossa, 2010 a; Mossa et al., 2011). Other authors revealed that the insecticides caused decrease in body weight of treated rats, may be due to the overall 
increased degradation of lipids and protiens, (Goel et al., 2005; Mansour and Mossa, 2011; Mossa et al., 2011).

Transfer and compartmentalization of the chemical from mother to fetuses through the placenta is an important factor for determining fetal resorption (Nau and Scott, 1985). Chemicals with a molecular weight less than 600 many readily transmigrate through the placenta (Mirkin, 1973). Every toxic material show the ability to penetrate the placenta barrier and thus can potentially affected the developing fetuses. The umbilical cord is a reservoir of stem cells which can be used to treat hematopoietic and genetic disorders, meconium and infant urine indicating exposure of the human fetuses to pesticides (Abu-Qare et al., 2000; Bradman et al., 2003). This placenta is a transient structure that establishes a functional connection between dam and fetuses. This matchless structure transfers all the nutrients required for development, eliminates fetal metabolic waste and synthesize hormones essentials to pregnancy (Desforges and Sibley, 2010). Many reports established the penetration of insecticides through the placenta barrier (Saxena et al., 1981; Dewan et al., 2013).

Also, placenta contains highly specialized trophoblastic cells that form a barrier between the maternal uterus and the fetuses. This is in agreement with the study of Houghton et al. (2000) that showed a decrease of placental weight parallel to the decrease of fetal body weight. A smaller placenta probably has a lower blood flow, resulting in significant fetal hypoxia that may lead to retarded intrauterine growth (Houghton et al., 2000). It is well known that insecticides cross the placenta barrier and can induce some changes in the development of placental structures. Drug or chemical-induced placenta injury subsequently result in fetal growth retardation resorption or teratogenicity (El Ghareeb et al., 2015).

Our results reveal that administration of fipronil at $1 / 10$ and $1 / 30 \mathrm{LD}_{50}$ associated with a decrease number of implantations and live fetuses, and an increased number of dead and early resorption. Also, the decrease in number of fetuses per mother might be attributed to the lack of oval production or of the basic cell constituent as a result of toxic material administration (Tuchmann, 1975). The exposure of pregnancy to pesticides is an important factor because it effects on organism, a mother and a fetus. Our results testing fipronil induced decrease in the number of fetuses as well as viable fetuses per mother, decrease in body weight and increase in implantation loss.

Our results in good agreement with those found by many authors applying many different toxic xenobiotic such as pesticides, (Pant et al., 1995; Sharma et al., 2005). It is known that the differentiation of the uterus to support embryo development and implantation is primarily coordinated by progesterone and estrogen, (Psychoyos, 1973; Paria et al., 1993). Therefore, hormonal alterations by endocrine disruptors such as CPF may interfere with blastocyst survival and implantation. It causes oxidative stress, this would destroy and damage the fallopian tube (Guney et al., 2007). This would cause an unfavorable environment for implantation of the blastocysts and prevent transportation of embryo into the uterus (Guney et al., 2007). Increase frequency of micronucleus lead to decrease in embryo cell number that is due to cytogenetic damage in the blastocyst (Tian and Yamauchi, 2003).

The fore and hind limbs not only showed lower degree of ossification but also because shorter as compared with the corresponding bones of the control fetuses. The reduced ossification of fetal skeletons may be a probable cause to lower fetal weight. Similar relationship between reduced fetal body weights and retarded ossification of the skeleton has been reported by Murray et al. (1979) following exposure to carbaryl in rabbits and mice. Incomplete ossification of most bones may be related to the effect of insecticide on calcium metabolism and/or bone morphometry by reducing the supply of calcium and magnesium ions to the growing fetuses thereby reducing retardation in the bone development (Andrews and Gray, 1990).

Moreover, the delay in ossification of skeletal system may be associated to the delay in fetal growth in the high dosed group. More attention should be paid to the possible effects of various toxic substances found in the 
environment; particularly those with low toxicity that are present in food and water as they could induce marked changes at the cellular level (Tezak et al., 1992). In general, the use of pesticides either of natural origin or traditional are must be controlled to avoid any hazards to the living especially humans. Due to the critical roles of reproductive hormones in reproductive process and embryonic development, the hormones imbalance may increase the rates of stillbirth, resorption and implantation loss (Kim et al., 2005). Recently, a novel study demonstrated that the exposure of organo phosphates breaks the balance of redox system and results in oxidative stress, a cytotoxic consequence of oxyradical and oxidant formation that usually cause extensive DNA damage (Manel et al., 2016).

The crosslinking of DNA is a type of DNA damage that is hard to be repaired, or repaired by error prone pathway but with great chance of mutagenesis. Additionally, elevated genomic damage is implicated in pesticide induced neurotoxicity (Mansour and Mossa, 2010b). Our results evidenced that the pesticides caused significant loss in fetal weight compared with the control this may be due to the toxicity of the pesticide itself (Manson and Kang, 1989) or may be explained by the decrease in food and water intake due to stress induced by exposure to repeated doses.

Harbison (1980) divided the critical period during mammalian development into an embryonic period and a fetal development period with most organogenesis complete during the trimester. Thus, the susceptible period for production of congenital malformation is the first trimester of pregnancy which is the stage of organ differentiation. Chemical teratogenensis is a challenging new area of toxicology. Some contaminants to which mammals may be exposed in the general environment or through occupational contact are teratogenics. Therefore, it seems wise to avoid exposure to these substances during pregnancy, particularly during the first trimester. It is important to be aware of the effect of pollutants at all stages of an organism life cycle before any statement can be made regarding concentration. (Weis and Weis, 1977). Such researches can serve in safety evaluation of toxic material to determine the maximum level at which no delectable deleterious effect can be observed, the so-called "maximum no effect level" (FDA, 1970). Evaluation of fetotoxicity/teratogenicity hazards represents an initial determination of approximate safety factor and assessment of a no-observed teratogenic effect dose level (Wang, 1988).

\section{REFERENCES}

Abou-Amer, L.W., F.A. Ali, M.I. Rady and A.E. Abdelmonem (2010). Teratological effects induced by three pesticides in pregnant rats. Alex. J. Pharm. Sci., 1: 21.

Abu-Qare, A.W., A. Abdel-Rahman, A.M. Kishk and M. Abou-Donia (2000). Placental transfer and pharmacokinetic of a single dermal dose of [14 C] methyl parathion rats. Toxicol. Sci., 53 : 5-12.

Andrews, J.E. and L.E. Gray (1990). The effects of lindane and linuron on calcium metabolism, bone morphometry and the kidney in rats. Toxicol., 60: 99-107.

Bradman, A., D.B. Barr, B.G. Claus-Henn, T. Drumheller, C. Curry and B. Eskenazi, (2003). Measurement of pesticides and other toxicants in amniotic fluid as a potential biomarker of prenatal exposure: a validation study. Environ. Health.

Chahoud, I. and T.E. Kwasigroch (1977). Controlled Breeding of Laboratory Animals. In: Neubert, D., Merker, H.J., Kwasigroch, T.E. (Eds.), Methods in Prenatal Toxicology Eval. Embryol. Effects in Exp. Anim. Berlin Teratol. Workshop, 78-91.

Dalsenter, P.R., A.S. Faqi, J. Webb, H.J. Merker and I. Chahoud (1997). Reprodutive toxicity and toxicokinetics of lindane in the male offspring of rats exposed durin lactation. Hum. Exp. Toxicol., 16 : 146-153.

Desforges, M. and C.P. Sibley (2010). Placental nutrient supply and fetal growth. Int. J. Dev. Biol., 54: 377-390.

Dewan, P., V. Jain, P. Gupta and B.D. Banerjee (2013). Organochlorine pesticide residues in maternal blood, cord blood, placenta and breastmilk and their relation to birth size. Chem., 90: 1704-1710. 
El Ghareeb, A.E.W., H. Hamdi, E.S.F. Taha and H. Ali (2015). Evaluation of teratogenic potentials of bronchodilator drug on offsprings of albino rats. Int. J. Scient. Eng. Res., 6: 534-542.

Faqi, A.S., P.R. Dalsenter, H.J. Merker and I. Chahoud (1998). Reproductive toxicity and tissue concentrations of low doses of 2,3,7,8tetrachlorodibenzo-p-dioxin in male offspring rats exposed throughout pregnancy and lactation. Toxicol. Appl. Pharmacol., 150 : 383-392.

FDA (1970). An advisory committee on protocols for safety evaluation, panel on reproduction: report on reproduction studies in the safety evaluation of food additives and pesticide residues. Toxicol. Appl. Pharma., $16: 264-296$.

Goel, A., V. Dani and D.K. Dhawan (2005). Protective effects of zinc on lipid peroxidation, antioxidant enzymes and hepatic histoarchitecture in chlorpyrifos-induced toxicity. Chem. Bio. Int., 156: 131-140.

Gray L.E., J. Ostby, E. Monosson and W.R. Kelce (1999). Environmental antiandrogens: low doses of the fungicide vinclozolin alter sexual differentiation of the male rat. Toxicol. Indus. Health, 15: 48-64.

Guney, M., B. Oral, H. Demirin, G. Take, S.G. Giray, I. Altuntas and T. Mungan (2007). Fallopian damage induced by organophosphate insecticide methyl parathion, and protective effect of vitamins $\mathrm{E}$ and $\mathrm{C}$ on ultrastructural changes in rats. Toxicol. Indus. Health, 23 : 429.

Harbison R.D. (1980). Teratogens, Chapter 8 in Toxicology, the Basic Science of Poisons, $2^{\text {nd }}$ Ed. Edited by Doull, Klaassen and Amdur. Macmillan Publishing Co.

Houghton, P.E., M.F. Mottola, J.H. Plust and C.L. Schachter (2000). Effect of maternal exercise on fetal and placental glycogen storage in the mature rat. Can. J. Appl. Physiol., 25: 443-452

Kim, S.S., S.J. Kwack, R.D. Lee, K.J. Lim, G.S. Rhee, J.H. Seok, B.H. Kim, Y.H. Won, G.S. Lee, E.B. Jeung, B.M. Lee and K.L. Park. (2005). Assessment of estrogenic and androgenic activities of tetramethrin in vitro and in vivo assays. J. Toxicol. Environ. Health, Part A, 68 : 2277-2289.

Lu, F.C. (1996). Basic Toxicology: Fundamentals, Target Organs and Risk Assessment. ${ }^{\text {rd }}$ Ed., Taylor and Francis, Washington, DC., USA., ISBN-13: 358.

Manel, A., N. Fadoua, D. Wahiba, K. Lamia, N.M. Fadhel, K. Abderraouf and H. Zohra (2016). Toxic effects of methamidophos on paraoxonase 1 activity and on rat kidney and liver and ameliorating effects of alphatocopherol. Environ. Toxicol., 31 : 842-854.

Manson, J.M. and Y.J. Kang (1989). Test methods for assessment of female reproductive and developmental toxicology. In: Hayes AW, editor. Prin. Methods Toxicol., 72-83.

Mansour, S.A. and A.H. Mossa (2010a). Oxidative damage, biochemical and histopathological alterations in rats exposed to chlorpyrifos and the antioxidant role of zinc. Pest. Biochem. Physiol., 96: 14-23.

Mansour, S.A. and A.H. Mossa (2010b). Adverse effects of lactational exposure to chlorpyrifos in suckling rats. Hum. Exp. Toxicol., 29: 77-92.

Mansour, S.A. and A.T.H. Mossa (2011). Adverse effects of exposure to low doses of chlorpyrifos in lactating rats. Toxicol. Ind. Health, 27: 213-224

Mirkin, B.L. (1973). Maternal and fetal distribution of drugs in pregnancy. Clin. Pharmacol. Therap., 14: 643-647.

Mossa, A.H., A.A. Refaie and A. Ramadan (2011). Effect of exposure to mixture of four organophosphate insecticides at no observed adverse effect level dose on rat liver: the protective role of vitamin C. Res. J. Environ. Toxic., 5: 323-335.

Murray, F.J., R.E. Staples and B.A. Schwetz, (1979). Teratogenic potential of carbaryl given to rabbits and mice by gavage or by dietary inclusion. Toxicol. Appl. Pharmacol., 51: 81-89.

Nau, H. and W.J. Scott (1985). Weak acids may act as human teratogen by accumulation in the young mammalian embryo. Nat., 332: 276-278. 
Nittin, S.D., A.K. Sharma, P. Dwivedi, R.D. Patil and M. Kumar (2007). Citrinin and endosulfan induced teratogenic effects in Wistar rats. J. Appl. Toxicol., 27: 143-151.

Ohi, M., P.R. Dalsenter, A.J.M. Andrade and A.J. Nascimento (2004). Reproductive adverse effects of fipronil in Wistar rats. Toxicol. Let., 146: 121-127.

Organisation for Economic Co-operation and Development Guidelines for Testing of Chemicals, Section 4 (2001). Test No. 414, Prenatal and Developmental Toxicity Study [website on the Internet]. Paris: OECD. Available from: http://www.oecd-ilibrary. org/ environment/ test-no-414-prenatal-development toxicity-study_ 9789264070820 -en.

Pant, N., A.K.S.C. Prasad, R.S. Srivastava and S.P. Srivastava (1995). Effect of oral administration of carbofuran on male reproductive system of rat. Human Exper. Toxicol., 14 (11): 889-894.

Paria, B.C., Y.M. Huet-Hudson and S.K. Dey (1993). Blastocyst's state of activity determines the 'window' of implantation in the mouse receptive uterus. Proc. Nat. Acad. Sci. USA, 90: 10159-10162.

Psychoyos, A. (1973). Endocrine Control of Egg Implantation. In: Greep, R.O., Astwood, E.G. Geiger, S.R. (Eds) Handbook of Physiology: Ame. Physiol. Soc., Washington DC., 187215.

Saxena, M.C., M.K.J. Siddiqui, A.K. Bhargava, C.R.K. Murti and D. Kutty (1981). Placental transfer of pesticides in humans. Arch. Toxicol., 48: 127-134.

Sharma, Y., S.B. Bashir, M. Irshad, S.D. Gupta and T.D. Dogra (2005). Effects of acute dimethoate administration on antioxidant status of liver, brain of experimental rats. Toxicol., 20: 49-57.

Staples, R.E. and V.L. Schnell (1964). Refinements in rapid clearing technique in the $\mathrm{KOH}$-alizarin red $\mathrm{S}$ method for fetal bone. Stain Technol., 39: $61-63$.

Teo, S., D. Stirling, S. Thomas, A. Hoberman, A. Kiorpes and V. Khetani (2002). A 90-days oral gavage toxicity study of Dmethylphenidate and D, Lmethylphenidate in Sprage-Dawley rats. Toxicol., 179 : 183-196.

Tezak, Z., B. Simic and J. Kniewald (1992). Effect of pesticides on oestradiol-receptor complex formation in rat uterus cytosol. Fd. Chem. Toxic., 30: 879-885.

Tian, Y. and T. Yamauchi (2003). Micronucleus formation in 3-day mouse embryos associated with maternal exposure to chlorpyrifos during the early preimplantation period. Reprod. Toxicol., 4: 401-405.

Tuchmann, H. (1975). Drug Effects on Faetus, ADIS press, New York, USA, $7: 4$.

US EPA (1996). US Environmental Protection Agency. Guidelines for Reproductive Toxicity Risk Assessment. EPA/630/R96/009. FRL-5630-6.Washington, DC, US EPA, 164.

Weis, S.J. and P. Weis (1977). J. Fish Biol., 11: 49.

Wang, G.M. (1988). Regulatory decision making and the need for the exposure data on pesticide determined to be teratogenic in test animals. Teratogen. Carcinogen. and Mutagen., 8: 117-126.

Wilson, J.G. (1965). Embryological consideration in teratology. In Wilson, J.G. and WarKany, J. (Eds.) teratology "Principles and Techniques" the university of Chicago Press. Chicageo and London, 251 - 277.

Yu, Y., Y. Yang, X. Zhao, X. Liu, J. Xue, J. Zhang and A. Yang (2015). Exposure to the mixture of organophosphorus pesticides is embryotoxic and teratogenic on gestational rats during the sensitive period. Wiley Period, Inc. Environ. Toxicol. 


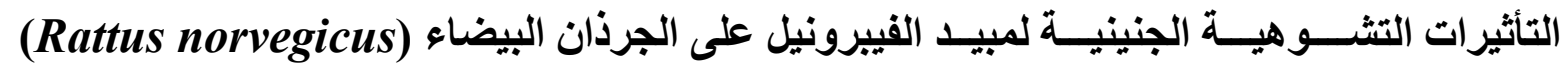
آمال عبد العزيز عيسى' - جمال العبد أبو الغار' - إبراهيم محمود عمار' ــ هالة جبر متولى ــ سماح سعيد عرفه'

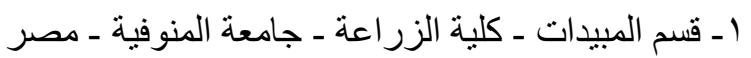

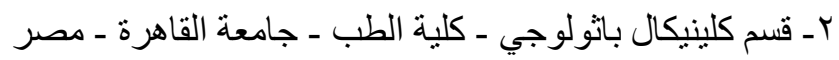

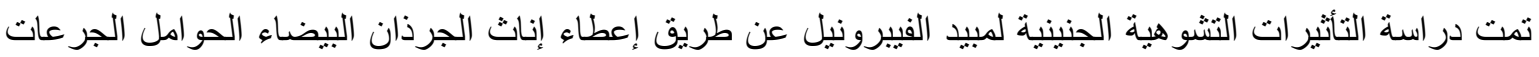

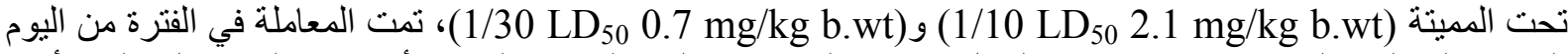

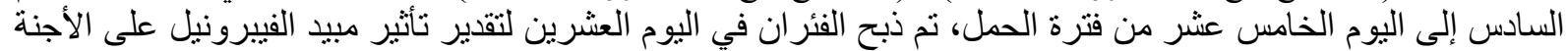

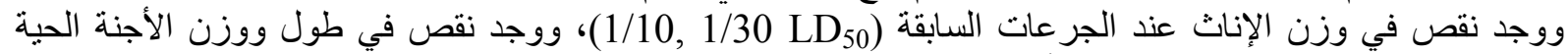

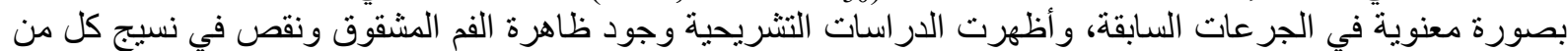

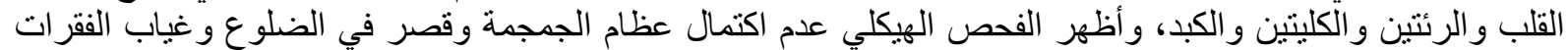
العصعصية مع غياب عظمة القص وسلاميات الأطر افت الخلفية والأمامية. 